\title{
Kompetensi Pedagogik Tuhan Yesus dalam Injil Matius Pasal 5-7
}

\author{
Ronald Yohanes Sinlae \\ Mahasiswa Program Doktoral Sekolah Tinggi Teologi Kadesi Yogyakarta
}

\begin{abstract}
In Matthew chapters 5-7 Jesus teaches His disciples on the Mount. Jesus does not need a particular school or building, every circumstance and meeting are always used to convey the word of God. In His Teaching, the Lord Jesus has the goal to discuss various topics about religion and morality in a scientific or theoretical manner and to serve everyone who comes to Him. Jesus knew and understood the Characteristics of the students and followers who were listening to His teachings. In the teaching process Jesus always taught in a special way. Jesus did not give a teaching and tell others to believe it, but encouraged them to think and draw their own conclusions about what had been explained to His disciples.
\end{abstract}

Keywords: Pedagogical Competence; Lord Jesus; Gospel of Matthew

\begin{abstract}
Abstrak
Di dalam Matius pasal 5-7 Yesus mengajar murid-murid-Nya di atas Bukit. Yesus tidak memerlukan sekolah atau gedung tertentu, setiap keadaan dan pertememuan selalu di gunakan untuk menyampaikan firman Allah. Dalam Pengajaran-Nya, Tuhan Yesus mempunyai tujuan untuk membahas berbagai topik tentang keagamaan dan kesusilaan secara ilmiah atau teori dan melayani setiap orang yang datang kepada-Nya. Yesus mengenal dan memahami Karakteristik murid-murid dan pengikut yang sedang mendengarkan pengajaran-Nya. Dalam proses pengajaran Yesus selalu mengajar dengan cara yang istimewa. Yesus tidak memberikan suatu ajaran dan menyuruh orang lain untuk mempercayainya, tetapi mendorong mereka untuk berpikir dan menarik kesimpulan sendiri atas hal yang telah dijelaskan kepada murid-murid-Nya.
\end{abstract}

Kata kunci: Kompetensi Pedagogik; Tuhan Yesus; Injil Matius 


\section{PENDAHULUAN}

Para pengajar masa Perjanjian Baru diawali oleh Yesus, dan dilanjutkan para rasul serta jemaat mula-mula. Bisa dikatakan bahwa pendidikan dalam Perjanjian Baru terkait erat dengan pribadi Yesus. Dalam Perjanjian Baru, Yesus adalah Guru yang biasa disebut Rabi. Yesus adalah seorang Guru yang sempurna dan tidak ada bandingannya di dunia. Dalam mengajar, Yesus memiliki kompetensi pedagogik. ${ }^{1}$

Di dalam Matius pasal 5-7 Yesus mengajar murid-murid-Nya di atas Bukit. Yesus tidak memerlukan sekolah atau gedung tertentu, setiap keadaan dan pertememuan selalu di gunakan untuk menyampaikan firman Allah. Dalam Pengajaran-Nya, Tuhan Yesus mempunyai tujuan untuk membahas berbagai topik tentang keagamaan dan kesusilaan secara ilmiah atau teori dan melayani setiap orang yang datang kepada-Nya. Yesus mengenal dan memahami Karakteristik murid-murid dan pengikut yang sedang mendengarkan pengajaran-Nya. Dalam proses pengajaran Yesus selalu mengajar dengan cara yang istimewa. Yesus tidak memberikan suatu ajaran dan menyuruh orang lain untuk mempercayainya, tetapi mendorong mereka untuk berpikir dan menarik kesimpulan

${ }^{1}$ Harianto GP, Pendidikan Agama Kristen dalam Alkitab dan Dunia Pendidikan Masa Kini (Yogyakarta: ANDI, 2012), 37. sendiri atas hal yang telah dijelaskan kepada murid-murid-Nya.

\section{Matius Pasal 5:1,2 dan Pasal 7:28,29}

Ketika Yesus melihat orang banyak itu, naiklah Ia ke atas bukit dan setelah Ia duduk, datanglah muridmurid-Nya kepada-Nya. Maka Yesuspun mulai berbicara dan mengajar mereka, ...

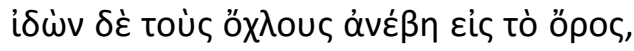

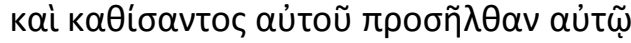

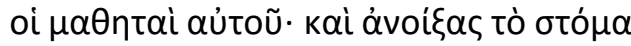

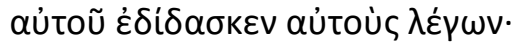

Dan setelah Yesus mengakhiri perkataan ini, takjublah orang banyak itu mendengar pengajaranNya, sebab Ia mengajar mereka sebagai orang yang berkuasa, tidak seperti ahli-ahli Taurat mereka.

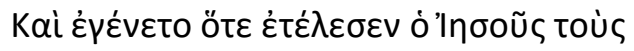

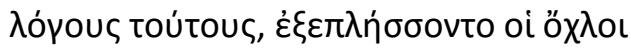

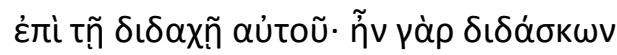
aủtoù

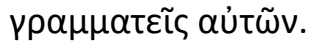

Ketika Yesus sampai di atas bukit, ia duduk memakai frasa $\kappa \alpha \theta i ́$ $\sigma \alpha v \tau o \varsigma$ yang 


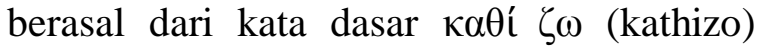
yang memiliki arti to seat, sit (untuk duduk dikursi) yang merupakan kata kerja partisip aorits aktif genetif maskulin tunggal. ${ }^{2}$ Dimana guru Yahudi biasanya mengajar sambil duduk, Yesus mengambil posisi yang biasa. Ketika Yesus duduk, dia membuka mulutnya dan mengajar mereka, yaitu , murid-muridnya yang datang kepadanya (ayat 1 ) . " Murid " (Yun. " pelajar ") adalah mereka yang telah membuat komitmen kepada Yesus sebagai Mesias ; "massa " (ayat 1) adalah orang-orang yang ingin tahu dan sering terkejut dengan ajaran-Nya dan pelayanan ( 7:28-29) namun untuk sebagian besar tetap netral dan tidak berkomitmen.

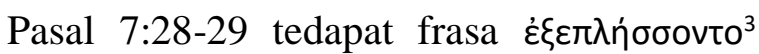

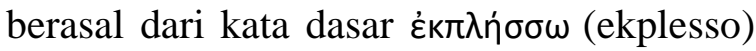
yang memiliki arti to amaze yang merupakan kata kerja indikatif pasif orang ke tiga jamak yang berarti menakjubkan. Kata kerja yang menunjukkan kesan heran yang ditunjukkan sebagai reaksi emosional kepada perkataan Yesus. Hal ini dapat terjadi karena Yesus mengajar dengan baik.

Kedua bagian teks tersebut menggambarkan betapa luar biasanya kemampuan pengajaran Tuhan Yesus. Kesan para pendengar menunjukkan bahwa pengajaran Tuhan Yesus sangat

\footnotetext{
${ }^{2}$ Hasan Susanto, Perjanjian Baru Interlinear Yunani-Indonesia (Jakarta: LAI, 2003) 16.

${ }^{3}$ Ibid, 25.
}

mengesankan bahkan penuh kuasa, meskipun pengajaran dilakukan kepada orang banyak dan tidak berlangsung dalam situasi kelas yang memampukan seorang guru untuk mempertahankan perhatian murid dalam penyampaian pengajarannya. Harianto GP dalam buku PAK dalam Alkitab dan Dunia Pendidikan Masa Kini mengemukakan bahwa:

Kata yang digunakan untuk menjelaskan belajar dan mengajar adalah "didasko" yang berarti "mengajar". Istilah ini paling banyak digunakan untuk menerangkan tentang tugas tugas Yesus, yaitu mengajar "paideuo" (memberikan membimbingan, mengajar, melatih. Kis. 7:22), "noutheo" (mempertajam pikiran 1 Kor. 4:14), "katekeo" (mengemukakan informasi, menyampaikan fakta. Luk. 1:4), "matheteuo" (menjadikan murid. Mat. 28:19), "oikodomeo" (membangun, membentuk. 1 Kor. 3:9), "Manthano" (belajar melalui praktik. Ibr. 5:8). ${ }^{4}$

Apabila digali lebih lanjut maka terdapat tiga kompetensi pedagogik yang menonjol dalam Matius 5-7 tersebut, yaitu:

1. Pengenalan karakteristik murid (Mat.

$$
\text { 5:21-24;33-37;7:28-29) }
$$

2. Pengelolaan proses pembelajaran (5:1-2; 7:28-29)

3. Komunikasi yang efektif $(5: 13 ; 7: 24-25)$

\section{Pengenalan Karakteristik Murid}

Tuhan Yesus dalam pengajaran-Nya menunjukkan bahwa Yesus mengenal karakteristik murid yang mendengar

${ }^{4}$ Mengutip: B. S. Sidjabat, Menjadi Guru Profesional sebuah Perspektif Kristiani (Bandung: Kalam Hidup, 2000), 17-18. 
pengajaran-Nya. Tuhan Yesus mampu mengarahkan, menuntun dan membimbing murid mengerti pengajaran yang diberikan, dan pengajaran-Nya membekas dalam ingatan murid-murid. Dengan demikian mengenal karakteristik murid-murid merupakan hal yang sangat penting dikarenakan pengenalan seorang guru terhadap karakteristik murid akan mempermudah guru dalam mengajar dan membimbing murid kepada keberhasilan dari proses pengajaran.

\section{Dalam Matius 5:21-24 Yesus} mengajarkan bahwa seorang murid harus mampu mengendalikan amarah, tidak menghina dan menghakimi sesama. Yesus mengingatkan kepada murid-murid untuk berusaha mengendalikan amarah yang dapat muncul dalam dirinya. Sebab pengendalian amarah adalah bagian dari karakteristik murid Kristus.

Yesus mengenal karakteristik setiap murid-murid yang sedang mendengarkan pengajaran-Nya di atas bukit. Salah satu karakteristik murid Yesus yang tidak sesuai dengan pengajaran Yesus adalah sulit untuk mengendalikan amarah. seperti yang dikatakan Kristanto: Petrus merupakan murid Yesus yang memiliki karakteristik

${ }^{5}$ Lilik Kristanto Paulus, Prinsip dan Praktik Pendidikan Agama Kristen (Yogyakarta: ANDI, 2008) 17. yang tidak sabaran, sulit mengendalikan amarah dan kasar. ${ }^{5}$

Dalam Matius 5:33-37 Yesus mengajarkan bahwa seorang murid harus mempunyai integritas dalam perkataannya. Karakteristik murid yang mempunyai intergritas dalam perkataan adalah setiap perkataan murid dipercaya oleh lingkungan. Jika "ya katakan ya jika tidak katakan tidak" merupakan suatu ketegasan dalam perkataan. Sehingga ketika murid-murid menyampaikan kebenaran tentang firman Tuhan setiap orang akan percaya karena murid-murid juga melakukan kebenaran firman Tuhan dalam kehidupan sehari-hari dan itu sangat berbeda dengan orang-orang farisi dan ahli Taurat.

Dalam pengajaran diatas bukit (Mat 5:33-37) tentang karakteristik yang berintegritas Yesus mengenal karakteristik murid-murid maupun para pendengar seperti ahli Taurat dan orang farisi yang pada waktu juga hadir untuk mendengarkan pengajaran Yesus di atas bukit. Yesus ingin mengajarkan kepada murid-murid-Nya melalui contoh dari karakteristik orang farisi dan ahli Taurat dalam membentuk murid-murid yang mempunyai karakteristik murid Kristus yang kuat dan menjadi teladan bagi semua orang.

Ketika Tuhan Yesus mengajar tidak pernah melakukan itu semata-mata karena 
harus mengajar. Ia selalu mempunyai tujuan yang ingin dicapai. Dan berusaha untuk mencapainya. Bahkan tujuan yang paling jelas yang Tuhan Yesus sampaikan adalah merubah perilaku orang yang menjadi penghuni kerajaan Surga. Dalam Matius 4:23 merangkum kisah-kisah pelayanan Tuhan Yesus yang meliputi mengajar $\delta\llcorner\delta a ́ \sigma \kappa \omega v$

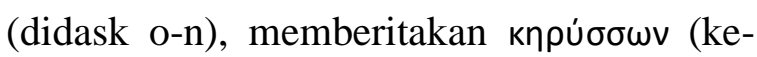
russo-n) dan melenyapkan penyakit

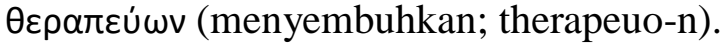

Di dalam Matius 7:28-29 setelah Yesus mengakhiri perkataan ini. Lenski mencatat kejituan dari pengamatan psikologis Matius. Ketika Yesus berbicara. orang banyak itu mendengarkan dengan penuh perhatian; tetapi ketika Dia berhenti, ketegangan menurun dan ketakjuban menguasai mereka (Interpretation of St. Matthew's Gospel, 314). Tidak seperti ahliahli Taurat mengingatkan kepada kenyataan bahwa ahli Taurat, waktu mengajar berkalikali mengutip pandangan para rabi yang terkemuka dan berbagai penafsiran tradisional. Betapa membosankan dibandingkan dengan kalimat penuh wibawa "Aku berkata kepadamu," yang diucapkan oleh Kristus.

Tuhan Yesus sebagai Guru menyentuh kebutuhan peserta didik melalui pengajaran dan perbuatan yang nyata. Dalam konteks ini murid-murid dan peserta didik lainnya sedang mengalami krisis kepercayaan oleh karena itu Tuhan Yesus memenuhi kebutuhan para peserta didik dengan mengajar dengan penuh kuasa.

Dalam perspektif iman Kristen memahami keberadaan peserta didik dalam kerusakan hubungannya dengan Allah, sesungguhnya Allah tetap mengasihi dan memperhatikan umat ciptaanNya ini. Alkitab menunjukkan betapa berharganya manusia di mata Allah. Tuhan Yesus sendiri mengatakan bahwa manusia jauh lebih berharga daripada burung pipit, bahkan jumlah rambut dikepala pun Tuhan ketahui (Mat. 10:30-31). Alkitab juga mengajarkan bahwa kehidupan dan jiwa manusia, sangat penting bagi Allah, dan inilah tujuan bagi manusia, yaitu untuk fokus terhadap hal-hal yang bersifat kekal, bukan duniawi. Hal-hal yang bersifat kekal adalah nyawa manusia, bukan harta atau hal lain di dunia ini (Mrk. 8:36; Mat. 6:25; Luk 12:15). Semua manusia, seberapa buruk sekalipun menurut pandangan manusia, sangat berharga di mata Tuhan, dan perlu diperhatikan dan dihargai karena merekapun tetap memiliki bagian dari kekekalan (Mat. 11:18; Mat. 18:20; Mat 18:12-24; Luk. 15:4-7). Bahkan sebegitu berharganya manusia, Allah sangat mengasihi manusia dan Allah sendiri rela menjelma 
menjadi manusia untuk menyelamatkan manusia dari maut (Yoh. 3:16; Fil. 2:7). ${ }^{6}$

Murid merupakan unsur terpenting dalam pembelajaran. Namun tidak ada diantara murid itu memiliki kesamaan. Dapat dipastikan bahwa setiap murid berbeda satu dengan yang lain.

Prof. Dr. S. Nasution, M.A dalam “Asas-asas Kurikulum” mengatakan,

Tak ada dua orang yang sama dalam segala hal di dunia ini. Selalu terdapat perbedaan antara dua individu karena pengaruh pembawaan dan lingkungan. Dari segi pembawaan hanya anak kembar identik yang sama, akan tetapi bila mereka ditempatkan dalam lingkungan yang jauh berbeda maka akan tampak berbagai perbedaan diantara mereka. Anak-anak saling berbeda, jasmaniah, rohaniah, emosional, dan sosial. Mereka juga berbeda dalam segi intelegensi, tinggi dan berat badan, tekanan darah, minat, stabilitas, emosional, kesehatan, kecepatan bereaksi, kecepatan membaca, ketrampilan berhitung, latar belakang, sosial ekonomi, pendidikan di rumah, kesukuan, agama, keterampilan, motoris, cita-cita dan dalam banyak hal lain, sehingga tak mungkin dua orang sama. ${ }^{7}$

\section{Sadirman menjelaskan tentang}

karakteristik sebagai berikut:

"Karakteristik peserta didik adalah keseluruhan kelakuan dan kemampuan yang ada pada peserta didik sebagai hasil dari pembawaan dan lingkungan sosialnya sehingga menentukan pola aktivitas dalam meraih cita-citanya. Dengan demikian, penentuan tujuan belajar itu sebenarnya harus dikaitkan atau disesuaikan dengan keadaan atau karakteristik peserta didik itu sendiri." 8

${ }^{6}$ Leon Marsh, Educational Psychology for Christian Education (Texas: Southwestern Baptis Theological Seminary Fort Worth, 1982), 4

${ }^{7}$ S. Nasution, Asas-asas Kurikulum (Jakarta: Bumi Aksara, 2008) 99.
Sebagaimana Tuhan Yesus memiliki pengenalan akan murid-murid-Nya sehingga pengajaran-Nya dapat diselenggerakan dengan baik serta berdampak luar biasa, maka pengenalan karakteristik murid juga menjadi tuntutan dalam pelaksanaan pengajaran di Sekolah Minggu. Terdapat empat tahap perkembangan anak murid Sekolah Minggu yang perlu menjadi perhatian dari para guru Sekolah Minggu baik kelas batita, balita, madya dan tunas remaja. $^{9}$

\section{$\underline{\text { Pengelolaan Proses Pembelajaran }}$}

Matius pasal 5-7 dalam peristiwa Khotbah di Bukit menunjukan bahwa Yesus memakai ceramah. Dalam pasal 5:1-2, frasa

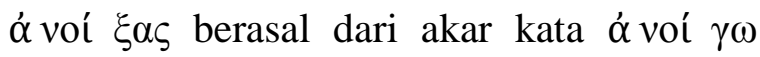
$(\text { an-oy'-go })^{10}$ merupakan kata kerja partisip aorist aktif nominatif maskulin tunggal yang memiiki arti to open (membuka). Kata tò $\sigma \tau o ́ ~ \mu \alpha \quad$ (stom'-a) merupakan kata benda umum tunggal akusatif bersifat netral yang memiliki arti a mouth (mulut). Kata

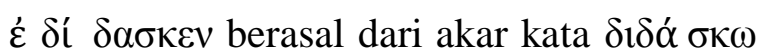
(didasko) merupakan kata kerja orang ketiga aktif tunggal impefect memiliki arti to teach (mengajar).kata $\lambda \varepsilon \dot{\varepsilon} \gamma \omega v$ berasal dari akar kata

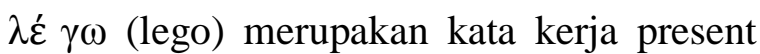

\footnotetext{
${ }^{8}$ Sadirman A.M., Interaksi dan Motivasi Belajar Mengajar (Jakarta: Rajawali Pers, 2009) 120.

${ }^{9}$ Marry Go Setiawani, Pembaharuan Mengajar, 21-31.

${ }^{10}$ Gerhard Kittel, 614.
} 
aktif nominatif maskulin tunggal, memiliki arti to say (mengatakan). Yesus membuka mulut mengajar murid-murid, berkata:.. dalam ayat ini merupakan peristiwa Yesus mengajar di atas bukit dengan menggunakan metode ceramah.

\section{Penggunaan Metode Pengajaran Yang} Tepat

Salah satu tugas penting seorang guru dalam mengajar adalah mengelolah kelas atau proses pembelajaran agar dapat terlaksana dengan baik dan semua komponen-komponen belajar dapat terintegrasi satu dengan yang lainnya selama proses pembelajaran berlangsung. Yesus dalam mengajar, memakai metode yang bervariasi. Yesus tidak membatasi diri dengan suatu metode dalam pengajaran-Nya.

J.M. price mengatakan:

"Tidak ada keterangan bahwa Yesus mempelajari metode prosedur mengajar dan dengan sengaja mempraktikan metode itu. Mungkin Yesus perna mempelajari hal itu, tetapi mungkin tidak. Yang jelas ialah bahwa Yesus sangat cakap mengajar dengan menggunakan metode-metode secara leluasa dan efisien. Tampaknya metode-metode itu diperoleh secara wajar. Dengan menghadapi setiap situasi yang timbul pada waktu mengajar dengan kecakapan yang sempurna." 11

\section{Sedangkan Peter P. Person}

menyatakan:

${ }^{11}$ Prince, J. M. A Survey of Religious Education (New York: The Ronald Press Company,1964), 14.

${ }^{12}$ Peter P. Person, an Introduction to Christian Education (Grand Rapids, Michigan: Baker Book House, 1979) 83.
"A careful study of the gospel indicates that the teaching methods Christ used werw not diffrent from those used by other teacher of this day. Any or all of the teaching techniques used by Jesus are available to the christian teacher of today."12

Dari pernyataan ini, bahwa metode yang digunakan Yesus pada waktu mengajar tidak berbeda dengan metode yang digunakan guru lain pada zaman itu. Bahkan semua teknik mengajar yang digunakan Yesus tersedia pada zaman sekarang ini. Selanjutnya James S. Stewart menyatakan: "Turning now from the particular features of Jesus method to its general principles, we notice, first, that it wurnas authoritative teaching"13 Pernyataan ini berarti bahwa keistimewaan metode Yesus adalah mempunyai wewenang dalam mengajar.

Di bawah ini akan diuraikan tentang metode yang digunakan Yesus dalam mengajar, yaitu: ceramah. Metode ceramah adalah: cara penyajian pelajaran yang dilakukan guru dengan penuturan atau penjelasan lisan secara langsung terhadap murid. $" 14$ Sementara menurut Permana:

"Metode ceramah atau kuliah mimbar adalah
penyajian pelajaran oleh guru dengan cara
memberikan penjelasan-penjelasan secara
lisan kepada murid-murid. penggunaan
metode ceramah sangat tergantung kepada
kemampuan guru. Karena gurulah yang
berperan penuh dalam metode ceramah.
Kepiawaian guru dalam menguasai bahan,

${ }^{13}$ James S. Stewart, The Life and Teaching (New York Nashville: Abingdon Press, T.th) 67.

${ }^{14}$ Syaiful Bahri Djamarah, Aswan Zain, Strategi Belajar Mengajar (Jakarta: Rineka Cipta, 2010) 97. 
forum/audience, dan ketrampilan bahasa serta intonasi sangat menentukan keberhasilan metode ini." 15

Tuhan Yesus di awal pengajaran-Nya memakai metode ceramah. Hal ini dapat dilihat ketika mengajar kepada orang banyak yaitu dalam Matius 5-7 dalam peristiwa Khotbah di Bukit. Rick Warren menyatakan: "satu ciri khas yang mengesankan dari pelayanan Yesus adalah bahwa cara itu menarik perhatian orang banyak dalam jumlah yang besar. ${ }^{16}$

Pengajaran Yesus pada waktu di bukit kepada murid-murid dan orang banyak Yesus memakai metode ceramah. Leroy Ford mengatakan: "metode ceramah adalah suatu pidato yang disampaikan oleh seorang pembicara dihadapan sekelompok pendengar."17 Tuhan Yesus, pada waktu menyampaikan khotbah di bukit di hadapan murid-murid dan orang banyak sehingga memakai metode ceramah ini. Metode ceramah digunakan Yesus dengan tujuan untuk menyampaikan pengetahuan kepada pendengar-Nya atau menafsirkan pengetahuan tersebut. Dengan metode ceramah ini, Yesus mengharapkan supaya murid-murid-Nya mengerti ajaran Yesus

\footnotetext{
${ }^{15}$ Johar Permana, Strategi Belajar Mengajar (Bandung:Maulana, 2001) 117.

${ }^{16}$ Rick Warren, The Purpose Driven Church (Malang: Gandum Mas, 2004) 213.

${ }^{17}$ Leroy Ford, A Primer For Teaching and Leaders (Bandung: Lembaga Literatur Baptis, T.th) 56.
}

yang mendalam. Setelah mengerti, tujuan Yesus adalah supaya murid-murid dan orang banyak mengalami perubahan dalam tingkah laku. Dr. Daniel Nuhamara mengatakan:

"Dengan metode ini Tuhan Yesus berusaha
menyampaikan pengetahuan kepada murid-
murid-Nya atau menafsirkan pengetahuan
tersebut. Melalui pendekatan ini Yesus
mengharapkan dua tanggapan dari para
murid-murid; pengertian mendalam dan
perilaku baru (Band. Khotbah di Bukit Mat
5-7). Melalui ceramah Yesus juga
mengajarkan serta memberikan bimbingan
kepada murid-murid-Nya."18

\section{Menurut William Barclay:}

"Yesus mulai mengajar setelah Ia duduk. Kalau ada seorang rabi Yahudi secara resmi mengajar, Ia akan duduk dan menyampaikan pengajarannya. Memang sering juga seseorang rabi Yahudi menyampaikan pengajaran sambil berdiri atau berjalan. Tetapi pengajaran yang resmi sebenarnya terjadi dengan sikap duduk di tempat yang telah disediakan.”

J.J. de Heer menyatakan bahwa: "seorang guru pada masa Alkitab duduk, sebab itu Matius mengatakan bahwa Yesus duduk. Artinya bahwa seorang guru pada masa Alkitab, kalau mengajar dalam posisi duduk. Dari dua pernyataan ini, berarti Yesus mengajar dalam suasana yang resmi dan sangat penting. ${ }^{19}$

Ungkapan "Yesus mulai berbicara" bukanlah suatu ungkapan biasa saja. Di

\footnotetext{
${ }^{18}$ Daniel Nuhamara, Pembimbing Pendidikan Agama Kristen (Bandung: Jurnal Info Media, 2009) 138.

${ }^{19}$ J.J. de Heer, Tafsiran Alkitab: Injil Matius 1 - 22 (Jakarta:BPK Gunung Mulia, 2000), 70
} 
dalam bahasa Yunani ungkapan itu dipakai sebagai ungkapan yang menunjukan ucapan penuh wibawa, serius, dan khidmat. Ungkapan itu dipakai seseorang yang membuka isi hatinya dengan tulus dan ikhlas, dan melahirkan atau mengutarakan segala sesuatu yang ada dalam pikirannya.

Dalam metode ceramah, guru lebih aktif berbicara dan murid cenderung pasif hanya diam mendengarkan. Akan tetapi dalam metode ceramah Yesus memulai dengan memakai pendahuluan yang menarik yaitu mengungkapkan kata-kata yang sangat penting. Hal ini membuat pendengar-Nya khususnya murid-murid tertarik untuk lebih tahu kelanjutan dari pengajaran-Nya. Dalam mengajar, Yesus memakai ketrampilan untuk membuka pelajaran, yaitu memakai suatu pendahuluan yang menarik sehingga membuat murid-murid-Nya ingin mengetahui isi pelajaran yang akan disampaikan. Ambarjaya menyatakan: "membuka pelajaran merupakan suatu kegiatan yang dilakukan guru untuk menciptakan kesiapan mental dan menarik perhatian murid secara optimal. Tujuannya agar mereka memusatkan diri sepenuhnya pada pelajaran yang akan disajikan."20

Salah satu kelemahan metode ceramah adalah kurang menarik. Tetapi

\footnotetext{
${ }^{20}$ Ambar Jaya, 45.

${ }^{21}$ Santoso, 59.

${ }^{22}$ Robert, R Bohlke, Sejarah Perkembangan Pikiran dan Praktek Pendidikan Agama Kristen : Dari
}

metode ceramah yang dipakai oleh Yesus adalah menarik bagi pendengar-Nya. Hal ini di buktikan dari kesan pendengar setelah mendengar pengajaran Yesus yaitu dalam Matius 7:28-29 yang berbunyi "dan setelah Yesus mengakhiri perkataan ini, takjublah orang banyak itu mendengar pengajaranNya. Sebab Ia mengajar mereka sebagai orang yang berkuasa, tidak seperti ahli-ahli Taurat mereka." Jadi artinya para pendengar terutama murid-murid kagum dengan pengajaran-Nya. Dr. David Iman Santoso menyatakan:

\begin{abstract}
"Ajaran dalam khotbah di bukit ini ternyata begitu indah, dalam dan agung, yang mau tidak mau membuat kita bertanya siapa sebenarnya sang Guru yang mengajarkan ajaran dengan standar etika dan moral yang begitu tinggi? Kami percaya, khotbah di bukit adalah khotbah Yesus yang adalah Juruselamat dunia kepada dunia yang membutuhkan Injil keselamatan."21
\end{abstract}

Dalam metode ceramah, Yesus menyampaikan ceramah-Nya dengan gaya yang menarik mengajar yang menarik menurut Roberth R. Boehlke: "Suara-Nya, air muka-Nya, gerak-gerik badan-Nya, sikapNya terhadap para pendengar, semuanya itu turut menarik perhatian orang banyak. Rupanya terdapat juga sesuatu dalam nada suara-Nya yang menimbulkan kepercayaan dalam diri pendengar-Nya. Apa yang diungkapkan-Nya dapat dipercaya."22

Yohanes Amos Comenius sampai perkembangan PAK di Indonesia (Jakarta, BPK Gunung Mulia 2003),5666. 
Metode ceramah adalah cara penyajian pelajaran yang disampaikan secara lisan oleh guru kepada murid.

\section{Dalam Matius 5:17 berbunyi:} "Janganlah kamu menyangka, bahwa Aku datang untuk meniadakan hukum Taurat atau kitab para nabi. Aku datang bukan untuk meniadakannya, melainkan untuk menggenapinya." frasa tò $v$ vó $\mu$ ov (nomos)

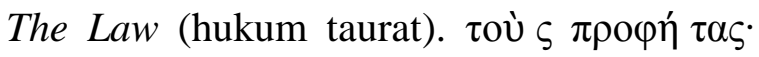
(prophetes) the Prophets (Kitab para nabi) dalam pengajaran Yesus menggunakan hukum taurat dan kitab para nabi sebagai sumber bahan mengajar. Pengajaran Yesus bukan meniadakan Hukum Taurat atau kitab para nabi, melainkan menggenapinya. Hal ini di buktikan dengan perkataan Yesus dalam beberapa pengajaran-Nya, "sebab ada tertulis" dan "kamu telah mendengar firman."

Dalam Matius 5:18-48 terdapat frasa

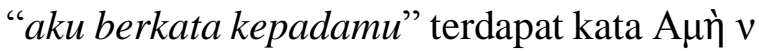
(amen) yang merupakan kata yang tak dapat berubah bentuknya yang memiliki arti Truly

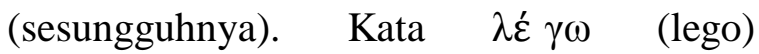
merupakan kata kerja present aktif nominatif maskulin tunggal, memiliki arti to say (mengatakan). Kata $\dot{v} \mu \tilde{\imath} v$ (hoo-min') merupakan kata ganti orang jamak datif, memiliki arti you (kamu). Terjemahanya "sesungguhnya aku mengatakan kepadamu." Dan frasa "kamu telah mendengar yang difirmankan" terdapat kata Hкоú $\sigma \alpha \tau \varepsilon$ berasal dari kata dasar ó кoú $\omega$ (ak-oo'-o) merupakan kata kerja aorist aktif indikatif orang kedua jamak yang memiliki arti to hear (mendengar). Kata ǒ $\tau$ (hot'-ee) merupakan kata yang mempunyai kaitan yang memiliki arti that, Because (bahwa, karena). Terjemahan "kamu telah mendengar bahwa apa yang dikatakan yaitu firman Tuhan" Dalam proses pembelajaran ini Yesus menggunakan metode penelaahan Alkitab.

Perjanjian Baru memuat banyak metode yang dipakai Tuhan Yesus dalam mendidik murid-murid-Nya. Semua metode yang dipakai-Nya masih sangat cocok untuk diterapkan pada pendidikan Kristen untuk anak-anak didik zaman ini. Tuhan Yesus menggunakan pepatah, ilustrasi, perumpamaan dalam memulai atau dalam menjalankan pengajaran. Bagi Price, susunan pengajaran pengajaran Yesus amat menarik, diawali pendahuluan, isi dan kesimpulan. Singkatnya, menurut price, metode Yesus amat variatif karena mencakup cerita, ceramah dan tanya jawab.

Berikut ini Dr. Leatha Humes, dkk.mengungkapkan cara dan metode mengajar Yesus sesuai dengan kontek Pendidikan Anak: Pertama, Tuhan Yesus mengajar melalui hidup dan perbuatan-Nya. Segala kelakuan-Nya sesuai dengan kehendak Allah dan menyatakan kasih dan kebenaran Allah kepada murid-murid-Nya. Tiap orang yang datang kepada-Nya 
mendapat perhatian-Nya. Dengan penuh kasih Ia menolong yang memerlukan pertolongan-Nya. Ia tidak segan melawan segala sesuatu yang tidak sesuai dengan kehendak Allah. Contoh yang konkrit dalam hidup seorang guru selalu lebih mengesankan daripada segala kata yang diucapkannya.

Kedua, Tuhan Yesus memakai pengalaman pendengar-pendengar-Nya untuk mengajar mereka. Sebagai dasar untuk ajaran yang baru, Ia menyebut hal-hal yang lazim dialami tiap orang, peristiwa-peristiwa dari hidup sehari- hari yang pasti akan dimengerti oleh setiap pendengar-Nya. Umpamanya menanam benih (Matius 13:19), memasang lampu (Matius 5:15-16), mencari sesuatu yang hilang (Lukas 15:110). Hal-hal seperti itu dapat dimengerti, dan juga akan mengingatkan mereka kepada ajaran itu tiap kali mereka melakukannya lagi.

Ketiga, Tuhan Yesus terkadang menunjukkan obyek-obyek yang konkrit untuk dilihat. Dengan memakai mata uang (Matius 12:13-17), burung di udara dan bunga-bungaan di padang (Matius 6:25-34) yang kelihatan di mana- mana sehingga akan mengingatkan pendengar-Nya akan ajaranNya tiap kali murid dan pengikut-Nya melihat barang itu kelak.

Keempat, Tuhan Yesus memakai cerita yang tepat dan sederhana untuk mengajar. Cerita-cerita berupa perumpamaan dan perbandingan yang sangat mengesankan dipakai-Nya utuk memikat perhatian orang dan menekankan kebenaran. Cerita-cerita itu sering dipakai-Nya untuk menjawab pertanyaan dan pendengar-Nya diajak berpikir sendiri mengenai maksud dan arti cerita itu (misalnya Lukas 10:25-37 dan 12:13-21). Cerita yang mengesankan tak akan terlupakan, sehingga ajaran yang terdapat di dalamnya makin mendalam bagi pendengarnya.

Kelima, Tuhan Yesus menyatakan motif-motif yang kuat untuk menerima ajaran-Nya. Tiap manusia cenderung menaruh perhatian besar pada kepentingan dirinya sendiri. Apa saja yang akan menolongnya untuk mencapai tujuannya, akan menarik perhatiannya. Tuhan Yesus selalu menunjukkan hubungan antara ajaran yang diberikan-Nya dengan kebutuhan yang sedang digumuli oleh para pendengar-Nya (misalnya Matius 11:28-29 dan Yohanes 11:25-26). Tetapi perhatikanlah: Persaingan atau harapan untuk memperoleh sesuatu yang berharga dalam dunia materi tak pernah dipakai-Nya sebagai motif untuk menerima ajaran-Nya.

Keenam, Tuhan Yesus selalu mengaktifkan pendengar-pendengar-Nya. Ia mengajak mereka bersoal-jawab; Ia mengajukan kepada mereka pertanyaanpertanyaan yang mendorong mereka untuk berpikir menemukan jawaban yang tepat. Ia 
memberikan kesempatan untuk berbuat sesuatu; murid-murid diajak memberi makan orang banyak (Matius 14:16-19). Mereka ditugaskan pergi meneruskan ajaran yang telah disampaikan-Nya kepada mereka (Lukas 10:1-9). Kita belajar jauh lebih banyak lewat apa yang kita lakukan daripada yang hanya kita dengarkan.

Ketujuh, Tuhan Yesus selalu memberikan kepada pendengar-Nya tanggung jawab untuk mengambil keputusan secara pribadi. Dengan jelas Ia menunjukkan akibat dari pilihan yang tepat dan yang tidak tepat. Tanggung jawab untuk memilih diserahkan sepenuhnya pada tiap pendengarNya. Ia tidak menyuruh mereka menghafalkan apa yang dikatakan-Nya dan taat secara mutlak tanpa berpikir. Sebaliknya, Ia mendorong mereka untuk berpikir sendiri dan mengambil keputusan dengan penuh kesadaran mengenai akibat pilihannya, yakin untuk mengikuti-Nya atau tidak. Ketaatan yang dipaksakan atau dilakukan tanpa pikir bukanlah ketaatan sejati. Keputusan yang sah ialah keputusan yang diambil dengan penuh pengertian dan kerelaan. ${ }^{23}$

\section{$\underline{\text { Penguasaan Materi Pengajaran }}$}

Pasal 5:1-2 dikatakan: "Ketika Yesus melihat orang banyak itu, naiklah Ia ke atas bukit dan setelah Ia duduk, datanglah murid-

${ }^{23}$ Leatha Humes dan A. Lieke Simanjuntak, Penuntun Guru PAK Sekolah Minggu dan Sekolah
murid-Nya kepada-Nya. Maka Yesuspun mulai berbicara dan mengajar mereka. Frasa

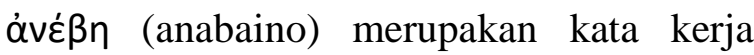
indikatif aorist aktif orang ketiga tuggal. Yang artinya go up (naik) عis tò őpos, (oros) merupakan kata benda akusatif tunggal. memiliki arti mountain, hill (gunung,bukit)

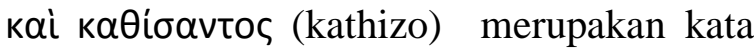
kerja partisip aorist aktif genetif maskulin tunggal. Artinya to sit (untuk duduk). Yesus naik ke atas bukit dan duduk disana untuk mempersiapkan pengajaran yang akan diberikan kepada murid-murid.

Hukum yang pertama dalam teori "tujuh hukum mengajar" dari John Milton Gregory berbunyi: "Guru harus mengetahui apa yang diajarkan.” Jika guru sendiri mengetahui jelas inti pelajaran yang akan disampaikan, ia dapat meyakinkan murid dengan wibawanya sehingga murid percaya apa yang dikatakan guru, bahkan merasa tertarik terhadap pelajaran.

Pertama, Mengetahui dengan jelas sasaran pengajaran. Pengajaran yang jelas sasarannya membuat murid melihat dengan jelas inti dari pokok pelajaran itu. Mereka dapat menangkap seluruh liputan pelajaran, bahkan mengalami kemajuan dalam proses belajar. Empat macam ciri khas yang harus diperhatikan pada saat memilih dan menuliskan sasaran pengajaran yaitu inti dari

Dasar: 1 dan 2 (Jakarta: BPK Gunung Mulia,1988) 23-24. 
sasaran harus disebutkan dengan jelas, ungkapan penting dari sasaran harus bertitik tolak dari konsep murid, sasaran harus meliputi hasil belajar, hasil sasaran yang dapat dicapai. Contoh: murid mengetahui dengan jelas hal-hal yang terjadi pada waktu perjalanan perkabaran Injil Paulus yang pertama kali. Murid memahami inti sari keselamatan atau dilahirkan kembali. Murid sudah dapat mempelajari pelajaran mengampuni orang lain. Murid dapat menguasai teknik ber-PI pribadi. Contohcontoh diatas telah menjelaskan empat macam hasil belajar yang berbeda: pengetahuan, pengertian, sikap, dan keterampilan.

Kedua, Utamakan susunan yang sistematis. Pengajaran yang tidak bersistem bagaikan sebuah lukisan yang semraut, tidak dapat memberikan kesan yang jelas bagi orang lain. Tidak adanya inti, tidak tersusun, tidak sistematis, akan sulit dipahami dan sulit diingat. Oleh sebab itu, inti pengajaran harus disusun dengan teratur dan sistematis.

Ketiga, banyak gunakan contoh kehidupan. Pada saat Yesus mengajar, Ia sering kali menggunakan contoh atau perumpamaan kehidupan sehari-hari, misalnya dalam khotbah diatas bukit, Ia telah menggunakan contoh-contoh sebagai berikut: keadaan alam (Mat :4-46), tumbuhtumbuhan dan binatang (Mat 6:26-30), organ tubuh manusia (Mat 29-30), kehidupan sehari-hari (Mat. 7:9-11), proyek bangunan (Mat 7:24-27), hukum pemerintah (Mat :2326), kehidupan beragama (Mat 6:5-8). Contoh kehidupan adalah jembatan antara kebenaran Alkitab dengan kehidupan yang nyata, yang membuat teori tidak terpisahkan dari kehidupan.

Keempat, cakap menggunakan bentuk cerita. Bentuk cerita tidak hanya diutarakan dengan kata-kata, namun juga boleh dicoba dengan menambahkan gerakangerakan, yang memperdalam kesan murid. bentuk yang paling lazim adalah menggunakan perumpamaan untuk menjelaskan kebenaran.

Kelima, menggunakan pancaindra murid. penggunaan bahan pengajaran yang berbentuk audio visual bukan saja cocok untuk sekolah dasar, menengah dan atas. Ensiklopedia adalah buku yang sering dipakai oleh para ilmuan, namun didalamnya terdapat banyak penjelasan yang menggunakan gambar-gambar. Itu berarti bahwa para ilmuwan pun perlu bantuan gambar-gambar untuk mengadakan catatan statistik selama 15 bulan, sebagai hasilnya mereka mendapat presentase dari isi pelajaran yang masih diingat oleh murid yang hanya tergantung pada indera pendengaran saja masih dapat mengingat $28 \%$, sedangkan bagi murid yang menggunakan indera pendengaran ditambah dengan indra penglihatan dapat mengingat $78 \%$. 
Keenam, melibatkan murid dalam pelajaran. Melibatkan murid dalam pelajaran dapat menambah ingatan mereka, juga motivasi dan kegemaran mereka. Cara itu dapat menghilangkan kesalahpahaman yang mungkin terjadi ditengah pertukaran pikiran antara guru dan murid, selain mengurangi tingkah laku yang mengacau. Misalnya: biarkanlah murid menggunakan kata-katanya sendiri untuk menjelaskan argumentasi atau pendapatnya; biarlah murid menggali dan menemukan hubungan antara konsep yang berbeda, biarlah murid bergerak sebentar. Jika murid sibuk melibatkan diri dengan pelajaran, maka tidak ada peluang lagi untuk mengacau atau membuat ulah.

Ketujuh, menguasai kejiwaan murid. Guru yang ingin memberikan pelajaran yang sesuai dengan kebutuhan murid, tentu harus memahami perkembangan jiwa murid pada setiap usia. Ia juga harus mengetahui dengan jelas kebutuhan dan masalah pribadi mereka. Pengertian antara guru dan murid adalah syarat utama dalam komunikasi timbal balik. Komunikasi yang lebih efektif.

Kedelapan, gunakanlah cara mengajar yang hidup. Sekalipun memiliki cara mengajar yang paling baik, namun jika terus digunakan dengan tidak perna diubah, maka cara itu akan kegunaannya dan membuat murid merasa jenuh. Cara yang

${ }^{24}$ Harinto GP, Pendidikan Agama Kristen dalam Alkitab dan Dunia Pendidikan Masa Kini, 37. terbaik adalah menggunakan cara mengajar yang bervariasi dan fleksibel, untuk menambah kesegaran.

Kesembilan, menjadikan diri sendiri sebagai teladan. Masalah umum para guru adalah dapat berbicara, namun tidak dapat melaksanakan. Pengajarannya ketat sekali, namun kehidupannya sendiri banyak cacat cela. Cara mengajar yang efektif adalah guru sendiri menjadikan diri sebagai teladan hidup untuk menyampaikan kebenaran, dan itu merupakan cara yang paling berpengaruh. Kewibawaan sesesorang terletak pada keselarasan antara teori dan praktek. Jikalau guru dapat menerapkan kebenaran yang diajarkan pada kehidupan pribadinya, maka ia pun memiliki wibawa untuk mengajar.

Para pengajar masa Perjanjian Baru diawali oleh Yesus, dan dilanjutkan para rasul serta jemaat mula-mula. Bisa dikatakan bahwa pendidikan dalam Perjanjian Baru terkait erat dengan Pribadi Yesus. Dalam Perjanjian Baru, Yesus adalah Guru yang biasa disebut Rabi. Yesus adalah seorang Guru yang sempurna dan tidak ada bandingannya di dunia. Dalam mengajar, Yesus memakai metode pengajaran yang variatif dan penuh wibawa. ${ }^{24}$ 


\section{$\underline{\text { Komunikasi yang Efektif }}$}

Matius 7:24-25 berbunyi: "Setiap orang yang mendengar perkataan-Ku ini dan melakukannya, ia sama dengan orang yang bijaksana, yang mendirikan rumahnya di atas batu. Kemudian turunlah hujan dan datanglah banjir, lalu angin melanda rumah itu, tetapi rumah itu tidak rubuh sebab didirikan di atas batu."

Frasa $\Pi \tilde{\alpha} \varsigma$ (pas) oũ $v$ (oon) ǒ $\sigma \tau \iota \varsigma$

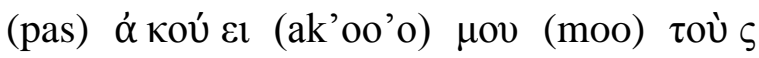

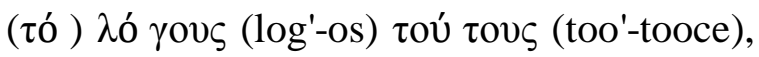
Therefore whosoever heareth these sayings of mine, "Setiap orang yang mendengar perkataan-Ku ini, memiliki arti yang sangat mendalam yaitu Tuhan Yesus dalam Ketrampilan berkomunikasi memakai kata $\lambda$ ó youৎ (log'-os) yang memiliki arti Firman.

Yesus memiliki kemampuan dan keahlian untuk menyampaikan informasi atau pesan kepada murid-murid-Nya. Dalam berkomunikasi, Yesus menggunakan bahasa yang santun, sopan, dan membangun orang lain. Yesus sangat cakap dalam menyampaikan informasi yang berhubungan dalam proses belajar mengajar, sehingga penjelasan, perintah, dan permintaan begitu jelas dan mudah dipahami oleh murid-muridNya. Demikian pula Yesus dalam menangkap respon atau reaksi dari

${ }^{25}$ Charles F. Pfeiffer, Tafsiran Alkitab Wycliffe (Malang: Gandum Mas,2001) 58. pendengarnya sebagai umpan bagi-Nya untuk memberikan tanggapan.

Dalam Matius 5:13 dikatakan "kamu adalah garam dunia jika garam itu menjadi tawar, dengan apakah ia diasinkan? Tidak ada lagi gunanya selain dibuang dan diinjak orang." Dalam berkomunikasi dengan murid-murid dalam proses belajar mengajar Yesus memberikan pertanyaan ini untuk mengungah pikiran murid-murid-Nya mengenai garam dan fungsinya untuk dikaitkan dengan pokok pengajaran-Nya mengenai tugas murid-murid Kristus yang terpanggil untuk menjadi berkat ditengahtegah dunia. ${ }^{25}$

Keberhasilan proses belajar turut ditentukan oleh kemampuan guru Sekolah Minggu dalam membangun interaksi positif dengan murid. Ada guru Sekolah Minggu yang cenderung hanya memberikan perhatian kepada anak-anak yang pandai, sedangkan yang kurang pandai diabaikan. Khususnya dalam proses belajar mengajar pendidikan agama Kristen dimana pencapaian kompetensi nampak melalui ada tidaknya transformasi nilai-nilai kehidupan, maka kemampuan guru berinteraksi dengan murid sangat penting. Jika tidak terjadi interaksi, maka guru kurang terbantu dalam memantau perubahan perilaku murid. Terutama pembelajaran pendidikan agama Kristen 
merupakan bagian dari komunikasi iman dilakukan guru dan murid dalam komunikasi secara efektif.

Dalam berkomunikasi dengan muridnya, seorang guru Sekolah Minggu sebaiknya tidak menggunakan istilah yang sulit dipahami. Juga guru sebaiknya menggunakan bahasa sehari-hari yang bisa dipahami oleh anak. Umumnya anak SD kelas 5 atau 6 sudah dapat memahami hampir semua istilah orang dewasa. Guru pengajar pada kelas ini boleh mulai mengajarkan istilah-istilah baku yang biasa digunakan di gereja, seperti istilah: dosa, bertobat, sidi, penebusan, dan sebagainya. Istilah-istilah tersebut sudah mulai dipahami, namun tetap memerlukan penjelasan yang baik.

Pengajaran pada dasarnya merupakan suatu proses terjadinya interaksi antara guru dengan murid melalui kegiatan terpadu dari dua bentuk kegiatan, yakni kegiatan belajar murid dengan kegiatan mengajar guru. Belajar pada hakikatnya adalah proses perubahan tingkah laku yang disadari. Mengajar pada hakikatnya adalah usaha yang direncanakan melalui pengaturan dan penyediaan kondisi yang memungkinkan murid melakukan berbagai kegiatan belajar sebaik mungkin.

Untuk mencapai interaksi belajar mengajar sudah barang tentu adanya komunikasi yang jelas antara guru (pengajar) dengan murid (pelajar) sehingga terpadunya dua kegiatan yakni kegiatan mengajar (usaha guru) dengan kegiatan belajar (tugas murid) yang berdaya guna dalam mencapai pengajaran. Sering kita jumpai kegagalan pengajaran disebabkan lemahnya sistem komunikasi, untuk itulah guru perlu mengembangkan pola komunikasi yang efektif dalam proses belajar mengajar. Ada tiga pola komunikasi yang dapat digunakan untuk mengembangkan interaksi dinamis antara guru dengan murid yaitu: komunikasi sebagai aksi atau komunikasi satu arah, komunikasi sebagai interaksi atau komunikasi dua arah, dan komunikasi banyak arah atau komunikasi sebagai transaksi.

Pertama, Komunikasi sebagai aksi atau komunikasi satu arah. Dalam komunikasi ini guru berperan sebagai pemberi aksi dan murid sebagai penerima aksi misalnya guru menerangkan pelajaran dengan menggunakan metode ceramah, sementara murid mendengarkan keterangan dari guru tersebut.

Kedua, Komunikasi sebagai interaksi atau komunikasi dua arah. Pada Komunikasi ini guru dan murid dapat berperan sama, yakni pemberi aksi dan penerima aksi sehingga keduanya dapat saling memberi dan menerima. Misalnya setelah guru memberi penjelasan pelajaran kepada muridnya, kemudian guru memberi 
pertanyaan kepada muridnya dan murid menjawab pertanyaan tersebut.

Ketiga, Komunikasi banyak arah atau komunikasi sebagai transaksi. Yakni komunikasi yang tidak hanya melibatkan interaksi dinamis antara guru dengan murid tetapi juga melibatkan interaksi dinamis antara murid yang satu dengan murid yang lainnya. Misalnya guru mengadakan diskusi dalam kelas.

\section{Dengan adanya tiga pola} komunikasi yang jelas dari komunikator kepada komunikan diharapkan dapat memperlancar proses kegiatan belajar mengajar secara efektif dan efisien. Komunikasi sangat berperan, karena dalam proses belajar terdapat unsur yang saling mempengaruhi. Dengan komunikasi, proses perubahan tingkah laku akan terjadi dari tidak tahu menjadi tahu, dan tidak paham menjadi paham. Dengan demikian komunikasi dapat menimbulkan efek sesuai dengan tujuan yang diharapkan, yaitu menumbuhkan motivasi belajar murid sehingga prestasi murid akan menjadi baik.

$$
\text { Untuk mengembangkan }
$$

kemandirian murid, diperlukan suatu kondisi yang memungkinkan murid belajar secara efektif semakin banyak murid melakukan komunikasi maka semakin dalam pengetahuannya. Semakin banyak murid melakukan komunikasi, maka kecakapan dan pengetahuan yang dimilikinya dapat semakin dikuasai dan semakin mendalam, karena komunikasi yang telah dilakukan akan membawa ke tingkat yang lebih baik.

Berdasarkan pemikiran di atas jelaslah bahwa motivasi belajar mempunyai hubungan yang erat dengan komunikasi yang dilakukan guru. Dengan demikian secara kronologi dapat dikatakan bahwa kreativitas komunikasi yang diberikan guru terhadap muridnya akan menjadikan semangat murid dalam belajar tinggi sehingga akhirnya akan mempengaruhi hasil belajar yang baik pula.

Menurut Dr. Bambang Yudho dalam bukunya How To Build Effective Communication mengatakan:

Untuk menciptakan komunikasi yang
efektif haruslah dilakukan secara dua arah,
saat masing-masing dapat mengajukan
pendapat, tanggapan dan pertanyaan
sehubungan dengan isi pengajaran yang
disampaikan. Sebagai seorang Guru
Sekolah Minggu Seharusnya menyediakan
waktu dalam komunikasi untuk memberi
kesempatan kepada murid untuk merespon
dengan benar.

Aktivitas bertanya dari murid merupakan rasa tertarik akan pengetahuan. Bertanya adalah cikal bakal anak mulai berfilsafat yang mestinya didukung, dipupuk, dan diberi ruang selebar-lebarnya.

Tuhan Yesus selalu berupaya menciptakan komunikasi dengan siapa saja 
dan tidak pernah menolak ataupun meremehkan orang lain. Zakeus dan perempuaan yang memberi minyak pada kaki-Nya dan tidak ditolaknya. Sebaliknya menerima perminyakan dari perempuan yang menurut penilaian masyarakat bukan perempuan baik-baik. Yesus juga menginap dirumah Zakeus, sang pemugut cukai yang diklaim sebagai manusia yang tamak yang penuh dosa oleh orang-orang Yahudi.

Yesus adalah guru agung yang begitu luar biasa pengajaran-Nya. Tanpa diminta oleh Yesus, orang banyak selalu berbondongbondong mengikuti kemana Dia pergi. Hal itu membuktikan bahwa Yesus adalah komunikator yang menarik orang banyak selalu mengikuti-Nya dan takjub akan pengajaran-Nya. (Mat 5).

Dalam menjalani panggilan-Nya, Yesus mengajar murid-murid-Nya serta masyarakat dalam peran yang berganti-ganti sesuai dengan kebutuhan konteks, baik situasi maupun pendengar. Bukanlah merupakan hal yang mudah bagi Yesus mengajar murid-murid-Nya yang memiliki berbagai karakter positif maupun negatif, misalnya Petrus yang kasar dan tidak sabar, Yohanes yang selalu bangga akan dirinya, Matius yang licik, Tomas yang selalu raguragu, Yudas sang pengkhianat, Yakobus dan Yohanes yang mengincar jabatan dan

${ }^{27}$ T.n, Christian Education of A Dynamic Process (Chicago: The Moody Bible Institute, 1981) kedudukan yang tinggi. Menurut Valarie A. Wilson: karakter murid-murid-Nya yang beragam merupakan tantangan bagi Yesus dan tidak pernah meninggalkan murid-murid karena berbagai karakter buruk yang merek miliki. Sebaliknya, Yesus selalu berupaya berkomunikasi secara efektif sesuai dengan karakter murid-murid sehingga Yesus mampu membantu mereka membangun karakter yang positif. ${ }^{27}$

\section{KESIMPULAN}

Pertama, Kompentesi pedagogik Yesus adalah mengenal karakteristik setiap murid-murid yang sedang mendengarkan pengajaran-Nya di atas bukit. "Karakteristik peserta didik yaitu keseluruhan kelakuan dan kemampuan yang ada pada peserta didik sebagai hasil dari pembawaan dan lingkungan sosialnya sehingga menentukan pola aktivitas dalam meraih cita-citanya. Dengan demikian, penentuan tujuan belajar itu sebenarnya harus dikaitkan atau disesuaikan dengan keadaan atau karakteristik peserta didik itu sendiri. Salah satu karakteristik murid Yesus yang tidak sesuai dengan pengajaran Yesus adalah sulit untuk mengendalikan amarah. Contohnya Petrus merupakan murid Yesus yang memiliki karakteristik yang tidak sabaran, sulit mengendalikan amarah dan kasar. 
Sebagaimana Tuhan Yesus memiliki pengenalan akan murid-murid-Nya sehingga pengajaran-Nya dapat diselenggerakan dengan baik serta berdampak luar biasa, maka pengenalan karakteristik murid juga menjadi tuntutan dalam pelaksanaan pengajaran di Sekolah Minggu dan sekolah umum.

Kedua, Kompetensi Pedagogik Yesus adalah mengelola proses pembelajaran. Salah satu tugas penting seorang guru dalam mengajar adalah mengelolah kelas atau proses pembelajaran agar dapat terlaksana dengan baik dan semua komponenkomponen belajar dapat terintegrasi satu dengan yang lainnya selama proses pembelajaran berlangsung. Dalam mengelola proses pembelajaran Tuhan Yesus menggunakan metode pengajarang yang tepat. Yesus dalam mengajar, memakai metode yang bervariasi. Yesus tidak membatasi diri dengan suatu metode dalam pengajaran-Nya. Didalam Matius Pasal 5-7 Tuhan Yesus, pada waktu menyampaikan khotbah di bukit di hadapan murid-murid dan orang banyak sehingga memakai metode ceramah. Metode ceramah digunakan Yesus dengan tujuan untuk menyampaikan pengetahuan kepada pendengar-Nya atau menafsirkan pengetahuan tersebut. Dengan metode ceramah ini, Yesus mengharapkan supaya murid-murid-Nya mengerti ajaran Yesus yang mendalam. Setelah mengerti, tujuan Yesus adalah supaya murid-murid dan orang banyak mengalami perubahan dalam tingkah laku. Dalam metode ceramah, guru lebih aktif berbicara dan murid cenderung pasif hanya diam mendengarkan. Akan tetapi dalam metode ceramah Yesus memulai dengan memakai pendahuluan yang menarik yaitu mengungkapkan kata-kata yang sangat penting. Hal ini membuat pendengar-Nya khususnya murid-murid tertarik untuk lebih tahu kelanjutan dari pengajaran-Nya. Dalam mengajar, Yesus memakai ketrampilan untuk membuka pelajaran, yaitu memakai suatu pendahuluan yang menarik sehingga membuat murid-murid-Nya ingin mengetahui isi pelajaran yang akan disampaikan. Yesus juga dalam pengajaranNya menguasai setiap Materi yang diajarkan. Karena Guru harus mengetahui apa yang diajarkan." Jika guru sendiri mengetahui jelas inti pelajaran yang akan disampaikan, ia dapat meyakinkan murid dengan wibawanya sehingga murid percaya apa yang dikatakan guru, bahkan merasa tertarik terhadap pelajaran.

Ketiga, Kompetensi Pedagogik Yesus adalah komunikasi secara efektif. Yesus memiliki kemampuan dan keahlian untuk menyampaikan informasi atau pesan kepada murid-murid-Nya. Dalam berkomunikasi, Yesus menggunakan bahasa yang santun, sopan, dan membangun orang lain. Yesus sangat cakap dalam 
menyampaikan informasi yang berhubungan dalam proses belajar mengajar, sehingga penjelasan, perintah, dan permintaan begitu jelas dan mudah dipahami oleh murid-muridNya. Demikian pula Yesus dalam menangkap respon atau reaksi dari pendengarnya sebagai umpan bagi-Nya untuk memberikan tanggapan. motivasi belajar mempunyai hubungan yang erat dengan komunikasi yang dilakukan guru. Dengan demikian secara kronologi dapat dikatakan bahwa kreativitas komunikasi yang diberikan guru terhadap muridnya akan menjadikan semangat murid dalam belajar yang tinggi sehingga akhirnya akan mempengaruhi hasil belajar yang baik. Yesus selalu berupaya berkomunikasi secara efektif sesuai dengan karakter murid-murid sehingga Yesus mampu membantu mereka membangun karakter yang positif. Soli Deo Gloria.

\section{DAFTAR PUSTAKA}

Barclay William, Pemahaman Alkitab Setiap Hari Injil Matius Pasal 1-10 Jakarta: Gunung Mulia, 2003

Bryant Alton T, The New Compact Bible Dictionary, Michigan : Zondervan Publishing House, 1967

Bohlke Robert, R. Sejarah Perkembangan Pikiran dan Praktek Pendidikan Agama Kristen : Dari Yohanes Amos Comenius sampai perkembangan PAK di Indonesia Jakarta, BPK Gunung Mulia 2003

Chapman Adina, Pengantar Perjanian Baru Bandung:Kalam Hidup,1995
Drewes F. B, Satu Injil Tiga Pekabar Jakarta: BPK Gunung Mulia, 2001

Douglas D. J, Ensiklopedi Alkitab Masa Kini: Jilid II (M-Z) Jakarta: Yayasan Bina Kasih/OMF, 2000

Djamarah Bahri Syaiful, Aswan Zain, Strategi Belajar Mengajar Jakarta: Rineka Cipta, 2010

E.G. Homrighausen dan LH. Enklaar, Pendidikan Agama Kristen Jakarta: BPK Gunung Mulia, 1987

Friedrich, Gerhard Theological dictionary of the New Testament 3 Grand Rapids, MI Eerdmans, 1976

GP Harinto, Pendidikan Agama Kristen dalam Alkitab dan Dunia Pendidikan Masa Kini Yogyakarta, ANDI, 2012

Gultom Andar, Profesionalisme, Standar Kompetensi, dan Pengembangan Profesi Guru PAK Bandung: Bina Media Informasi, 2007

Hakh Samuel, B. Perjanjian Baru: Sejarah, Pengantar dan Pokok-pokok Teologisnya Bandung: Bina Media Informasi, 2010

Haroul K. Moulton, Leksikon Analitis Bahasa Yunani Jogjakarta : Randa's

Family Press, 2009

Hamalik Oemar, Pendidikan guru: berdasarkan pendekatan kompetensi Jakarta: Bumi Aksara, 2002

Humes Leatha dan A. Lieke Simanjuntak, Penuntun Guru PAK Sekolah Minggu dan Sekolah Dasar: 1 dan 2 Jakarta: BPK Gunung Mulia,1988

Humer L, Arah Pendidikan Kristen Malang: Yayasan Persekutuan Pekabaran Injil Indonesia, 1983

Leroy Ford, A Primer For Teaching and Leaders Bandung: Lembaga Literatur Baptis, T.th

Leo Sutanto, Kiat Sukses Mengelola dan Mengajar sekolah Minggu Yogyakarta: ANDI, 2008, 2.

Lilik Paulus, Prinsip dan Praktik Pendidikan Agama Kristen Yogyakarta:

Andi, 2006

Marsh Leon, Educational Psychology for Christian Education Texas: Southwestern Baptis Theological Seminary Fort Worth, 1982 
Marxsen Willi, Pengantar Perjanjian Baru Pendekatan Kritis terhadap Masalahmasalah Jakarta: BPK Gunung Mulia, 2008

Nasution S, Kurikulum dan Pengajaran Bandung: Bumi Aksara, 2008

Nasution S, Asas-asas Kurikulum Jakarta: Bumi Aksara, 2008

Nuhamara Daniel, Pembimbing Pendidikan Agama Kristen Bandung: Jurnal Info Media, 2009

Nuhamara Daniel DKK, Mata Kuliah Pengembangan Kepribadian untuk Mahasiswa di Perguruan Tinggi Pendidikan Agama Kristen Bandung: Bina Media Informasi, 2005

Permana Johar, Strategi Belajar Mengajar Bandung:Maulana, 2001

Person Peter, P. an Introduction to Christian Education (Grand Rapids, Michigan: Baker Book House, 1979

Pfeiffer Charles, F. Tafsiran Alkitab Wycliffe Malang: Gandum Mas,2001

Prince, J. M. A Survey of Religious Education New York: The Ronald

Press Company,1964

Riemer G. Ajarlah Mereka Jakarta: Yayasan Komunikasi Bina Kasih/OMF, 2006

Riduwan, Metode dan Teknik Menyusun Tesis Bandung: Alfabeta, 2010

Sadulloh Uyoh, dkk., Pedagogik (Ilmu Mendidik) Bandung: ALFABETA, 2010

Sadirman, M. A. Interaksi dan Motivasi Belajar Mengajar Jakarta: Rajawali Pers, 2009

Salim Peter \& Yenny Salim, Kamus Bahasa Indonesia Kontemporer Jakarta: Modern English Press, 1991

Setiawani Go Marry, Pembaharuan Mengajar (Bandung: Yayasan Kalam Hidup, 2003)

Susanto Hasan, Perjanjian Baru Interlinear Yunani-Indonesia Jakarta: LAI, 2003

Sidjabat Samuel, B. Menjadi Guru Profesional sebuah Perspektif Kristiani Bandung: Kalam Hidup, 2000

Sidjabat Binsen Samuel, Membesarkan Anak dengan Kreatif, Panduan Menanamkan Iman dan Moral kepada
Anak Sejak Dini Yogyakarta: ANDI, 2008

T.n. Christian Education of A Dynamic Process Chicago: The Moody Bible Institute, 1981

Warren Rick, The Purpose Driven Church Malang: Gandum Mas, 2004

Warren Benson S. dan Mark H. Senter III, Pedoman Lengkap Untuk Pelayanan Kaum Muda 2 Bandung : Yayasan Kalam Hidup, 1999

Wibowo Jatmiko Alexander dan Fandy Tjipto, Pendidikan Berbasis Kompetensi Yogyakarta: ANDI Offset, 2002

Winarno Surkhamad, Pengantar Penelitian Ilmiah: Metode, Dasar, Teknik Bandung: Tarsito, 1990

Yudho Bambang, How to Build Effective Communication Yogyakarta: ANDI, 2010 